\title{
Arm fat and muscle areas in infancy
}

\author{
L SANN, M DURAND, J PICARD, Y LASNE, AND M BETHENOD
}

Faculté Lyon-Nord and Hôpital Debrousse, Lyon, France

SUMMARY Growth of arm muscle, fat and water areas were evaluated longitudinally in a prospective study in 81 infants from birth to the age of 12 months. The percentage of arm fat area $v$ the cross sectional upper arm area increased at the age of 15 days with a peak at the age of 6 months while arm muscle area increased progressively throughout the year. As arm water area represented only $1 \%$ of cross sectional upper arm area, calculations of arm fat and muscle areas can be carried out from measurements of mid arm circumference and tricipital skinfold at 15 seconds. Percentiles are presented for the upper arm fat and muscle areas, which can be used as index for the infants' nutritional state.

The evaluation of the nutritional state of infants is an important problem because according to Merritt and Susskind one third of infants in hospital are at risk from malnutrition. ${ }^{1}$ Recently anthropometric evaluations of the upper limb have become useful as indicators of the nutritional state of children and adults. It is assumed that the triceps skinfold thickness indicates the calorie reserve and the arm size reflects the reserve of protein. ${ }^{2-4}$ Gurney and Jelliffee pointed out that the cross sectional arm areas represent better estimates of the relative contribution of fat and muscle to the total arm area than mid arm circumference and triceps skinfold. ${ }^{4}$ To our knowledge there is no report of these arm areas measured at birth and then measured regularly throughout the first year of life. Therefore the first aim of this study was to report these mid arm fat and muscle areas from measurements collected prospectively in a population of 100 infants and to provide preliminary norms for the nutritional state of infants.

In neonates Thornton et al showed that the dynamic change of tricipital skinfold thickness is related to extracellular water content. ${ }^{5}$ It is not known to what extent these dynamic changes could influence the results of arm fat and muscle areas during infancy. The second aim of this study was therefore to look at this dynamic change in tricipital skinfold thickness in order to evaluate its magnitude.

\section{Subjects and methods}

This prospective longitudinal study was designated for a target number of 100 infants born at the Centre
Hospitalier Lucien Hussel of Vienne (Isère, France) between 2 January 1984 and 30 December 1985 . The following conditions were required for inclusion into the study: parent's informed acceptance and good comprehension of the French language and parents living within $20 \mathrm{~km}$ of the town. The neonates who were included were born at full term with a birth weight of more than $2500 \mathrm{~g}$, an Apgar score $>6$ at 5 minutes, and with no detectable malformation at clinical examination. Measurements were taken at birth (that is, before 3 days of age), and follow up measurements at 15 days ( \pm three days); one month ( \pm three days); and at four, six, nine, and 12 months ( \pm seven days). Unscheduled losses, however, occurred during the study mostly because of a refusal to continue the study, or the family changed address, and the practical impossibility of keeping to the scheduled timing. Altogether 81 neonates were finally included in the study and 64 infants were measured at the age of 12 months. This sample had a large representation of families of high socioeconomic state as $88 \%$ of the fathers belonged to the second or third category of the classification of Goujard et at - that is, civil servants, trained personnel, tradesmen, and farm owners. An analysis of dietary data showed that the proportion of breast fed infants was $75 \%$ at birth, $59 \%$ at the age of 15 days, $45 \%$ at the age of one month, $30 \%$ at the age of 2 months, and $7 \%$ at the age of 4 and 6 months. The formula milks given were in agreement with the recommendations of the European Society for Pediatric Gastroenterology and Nutrition (ESGAN) but at the age of 6 months $33 \%$ of the infants were given their diet as half cream cows' milk; this increased $42 \%$ at the age of 12 months. 
Additional intake was not evaluated in each case with adequate precision.

All measurements were collected in hospital or at home by one of us (MD). All upper arm measurements were done on the left side at exactly the mid distance between the acromion and the tip of olecranon. Weight was measured with a SECA-745 $A$ balance to the nearest $10 \mathrm{~g}$. Length of body was determined with a SECA-somatometer to the nearest $0.5 \mathrm{~cm}$. Head and mid arm circumferences were evaluated to the nearest $\mathrm{mm}$ using a plastic tape. All these measurements were done according to the methods of Sempé et al. ${ }^{7}$ Tricipital and scapular skinfold were measured with a Harpenden caliper using the technique of Brans et al. $^{8}$ Measurements to the nearest $0 \cdot 1 \mathrm{~mm}$ were obtained exactly 15 and 60 seconds after application of the caliper. The coefficient of variation of each measurement was lower than $5 \%$ with ranges between $1.5 \%$ for the mid arm circumference to $4.5 \%$ for the tricipital skinfold.

The calculated items included arm areas according to the equations given by Gurney and Jelliffee. ${ }^{4}$ They assume that the upper arm is cylindrical in form and that no variation occurs in humeral diameter. Slight modifications of the equations were introduced to allow consideration of the dynamic changes of tricipital skinfold: the timing of the measurement is not normally considered in the equations but in the present study arm muscle area (AMA) was determined from the tricipital skinfold measured at 15 seconds (TSKF15), and the arm fat area (AFA) was calculated from the tricipital skinfold measured at 60 seconds (TSKF60). The findings of Brans $e t a l^{8}$ and Thornton et $a l^{5}$ on the dynamic changes of tricipital skinfold showed that in neonates skinfold thickness compressibility or expressibility is intimately related to extracellular water content of the body. Therefore we estimated the arm water area (AWA) from the total area with the subtraction of AMA (measured from TSKF15) and of AFA (measured from TSKF60).

Thus: Arm area:

$$
\mathrm{AA}=\mathrm{MAC}^{2} / 4 \Pi
$$

Arm muscle area:

$$
\text { AMA }=(\text { MAC }-\Pi \text { TSKF15 })^{2} / 4 \Pi
$$

Arm fat area:

$$
\begin{gathered}
\text { AFA }=\mathrm{AA}-\frac{(\mathrm{MAC}-\Pi \mathrm{TSKF} 60)^{2}}{4 \Pi} \\
\text { Arm water area: } \\
\text { AWA }=\mathrm{AA}-\mathrm{AMA}-\mathrm{AFA}
\end{gathered}
$$

The results are all expressed in $\mathrm{mm}$.

The results are expressed as mean (SD). Statistical comparisons were carried out using the test of Kruskal and Wallis.

\section{Results}

Anthropometric measurements are given in table 1 . A significant difference between girls and boys was found for each measurement at each age with the exception of age 15 days and mid arm circumference from birth to 1 month of age. The results of tricipital

\begin{tabular}{|c|c|c|c|c|c|}
\hline Age & $\begin{array}{l}\text { Sex } \\
(N o)\end{array}$ & $\begin{array}{l}\text { Weight } \\
(g)\end{array}$ & $\begin{array}{l}\text { Length } \\
\text { of body } \\
(\mathrm{cm})\end{array}$ & $\begin{array}{l}\text { Head } \\
\text { circumference } \\
(\mathrm{cm})\end{array}$ & $\begin{array}{l}\text { Mid arm } \\
\text { circumference } \\
(\mathrm{cm})\end{array}$ \\
\hline 15 days & $\begin{array}{l}\text { Boys (25) } \\
\text { Girls (42) }\end{array}$ & $\begin{array}{ll}3665 & (372) \\
3482 & (431)\end{array}$ & $\begin{array}{l}51.7(1.5) \\
51.0(1.8)\end{array}$ & $\begin{array}{l}36.3(1.0) \\
35.5(1.0)\end{array}$ & $\begin{array}{l}10.7(0.7) \\
10.6(0.8)\end{array}$ \\
\hline 1 month & $\begin{array}{l}\text { Boys (27) } \\
\text { Girls (46) }\end{array}$ & $\begin{array}{ll}4261 & (352) \\
4008 & (437)\end{array}$ & $\begin{array}{l}53.9(1.3) \\
52.9(1.8)\end{array}$ & $\begin{array}{l}37.7(0.8) \\
36.9(0.7)\end{array}$ & $\begin{array}{l}11 \cdot 6(0.7) \\
11.3(0.8)\end{array}$ \\
\hline 4 months & $\begin{array}{l}\text { Boys (30) } \\
\text { Girls (39) }\end{array}$ & $\begin{array}{l}6890(646) \\
6319(724)\end{array}$ & $\begin{array}{l}63.4(1.7) \\
62.0(2.4)\end{array}$ & $\begin{array}{l}42 \cdot 6(0 \cdot 9) \\
41 \cdot 1 \quad(0 \cdot 8)\end{array}$ & $\begin{array}{l}14 \cdot 3(0.9) \\
13 \cdot 8(1 \cdot 1)\end{array}$ \\
\hline 6 months & $\begin{array}{l}\text { Boys (27) } \\
\text { Girls (42) }\end{array}$ & $\begin{array}{l}8036(770) \\
7259(834)\end{array}$ & $\begin{array}{l}67.6(1.8) \\
65.6(2.4)\end{array}$ & $\begin{array}{l}43.3(1.0) \\
42.9(1.0)\end{array}$ & $\begin{array}{l}15 \cdot 0(1 \cdot 2) \\
14 \cdot 2(1 \cdot 0)\end{array}$ \\
\hline 9 months & $\begin{array}{l}\text { Boys (25) } \\
\text { Girls (39) }\end{array}$ & $\begin{array}{l}9128(716) \\
8356(874)\end{array}$ & $\begin{array}{l}70.9(1.9) \\
69.6(2.4)\end{array}$ & $\begin{array}{l}45 \cdot 9(1 \cdot 1) \\
44 \cdot 6(1 \cdot 2)\end{array}$ & $\begin{array}{l}15 \cdot 6(1 \cdot 0) \\
14 \cdot 8(1.0)\end{array}$ \\
\hline 12 months & $\begin{array}{l}\text { Boys (25) } \\
\text { Girls (39) }\end{array}$ & $\begin{array}{r}10070(960) \\
9320(963)\end{array}$ & $\begin{array}{l}75 \cdot 5(2 \cdot 2) \\
73.4(2 \cdot 5)\end{array}$ & $\begin{array}{l}47 \cdot 4(1 \cdot 1) \\
45 \cdot 6(1 \cdot 0)\end{array}$ & $\begin{array}{l}15 \cdot 7(1 \cdot 2) \\
15 \cdot 3(0 \cdot 9)\end{array}$ \\
\hline
\end{tabular}
skinfold at 60 seconds and the different arm areas are shown in table 2 . The only significant difference between girls and boys was observed for arm muscle

Table 1 Anthropometric data of the infants studied (mean (SD)) 
Table 2 Results of measurements taken throughout the study (mean (SD))

\begin{tabular}{|c|c|c|c|c|c|c|c|}
\hline Age & $\begin{array}{l}\text { Sex } \\
(\mathrm{No})\end{array}$ & $\begin{array}{l}\text { Tricipital } \\
\text { skinfold } \\
\text { thickness at } \\
60 \text { seconds } \\
(\mathrm{mm})\end{array}$ & $\begin{array}{l}\text { Arm } \\
\text { area } \\
\left(\mathrm{mm}^{2}\right)\end{array}$ & $\begin{array}{l}\text { Arm } \\
\text { muscle } \\
\text { area } \\
\left(\mathrm{mm}^{2}\right)\end{array}$ & $\begin{array}{l}\text { Arm } \\
\text { water } \\
\text { area } \\
\left(\mathrm{mm}^{2}\right)\end{array}$ & $\begin{array}{l}\text { Arm } \\
\text { fat } \\
\text { area } \\
\left(\mathrm{mm}^{2}\right)\end{array}$ & $\begin{array}{l}\text { Arm } \\
\text { fat } \\
\text { area } \\
(\%)\end{array}$ \\
\hline Neonate & $\begin{array}{l}\text { Boys (32) } \\
\text { Girls (49) }\end{array}$ & $\begin{array}{l}4 \cdot 20(0 \cdot 7) \\
4 \cdot 15(0 \cdot 8)\end{array}$ & $\begin{array}{l}864(116) \\
835(135)\end{array}$ & $\begin{array}{l}643(89) \\
617(91)\end{array}$ & $\begin{array}{l}15 \cdot 0(5 \cdot 7) \\
17 \cdot 7(7 \cdot 4)\end{array}$ & $\begin{array}{l}205(42) \\
200(51)\end{array}$ & $\begin{array}{l}23.7(3.4) \\
23.7(3.3)\end{array}$ \\
\hline 15 days & $\begin{array}{l}\text { Boys (25) } \\
\text { Girls (42) }\end{array}$ & $\begin{array}{l}5 \cdot 10(0 \cdot 8) \\
5 \cdot 30(0 \cdot 9)\end{array}$ & $\begin{array}{l}916(129) \\
906(138)\end{array}$ & $\begin{array}{l}645(91) \\
628(91)\end{array}$ & $\begin{array}{l}16 \cdot 9(5 \cdot 7) \\
17 \cdot 3(7 \cdot 5)\end{array}$ & $\begin{array}{l}254(52) \\
261(55)\end{array}$ & $\begin{array}{l}27.6(3.7) \\
28.7(3.8)\end{array}$ \\
\hline 1 month & $\begin{array}{l}\text { Boys (27) } \\
\text { Girls (46) }\end{array}$ & $\begin{array}{l}5.80(0.9) \\
6.40(1.2)\end{array}$ & $\begin{array}{l}1078(138) \\
1022(143)\end{array}$ & $\begin{array}{l}746(95) \\
674(96)\end{array}$ & $\begin{array}{l}19 \cdot 1(8 \cdot 8) \\
18 \cdot 2(8 \cdot 2)\end{array}$ & $\begin{array}{l}313(61) \\
331(72)\end{array}$ & $\begin{array}{l}28.9(3 \cdot 7) \\
32 \cdot 2(4 \cdot 3)\end{array}$ \\
\hline 4 months & $\begin{array}{l}\text { Boys (30) } \\
\text { Girls (39) }\end{array}$ & $\begin{array}{l}8.90(1.3) \\
8.60(1.5)\end{array}$ & $\begin{array}{l}1644(212) \\
1522(242)\end{array}$ & $\begin{array}{r}1047(161) \\
962(177)\end{array}$ & $\begin{array}{l}19 \cdot 8(6 \cdot 6) \\
25 \cdot 4(11 \cdot 0)\end{array}$ & $\begin{array}{l}577(100) \\
534(110)\end{array}$ & $\begin{array}{l}35 \cdot 1(4 \cdot 4) \\
35 \cdot 1(5 \cdot 0)\end{array}$ \\
\hline 6 months & $\begin{array}{l}\text { Boys (27) } \\
\text { Girls (42) }\end{array}$ & $\begin{array}{l}9.50(1 \cdot 6) \\
9 \cdot 60(2 \cdot 1)\end{array}$ & $\begin{array}{l}1804(280) \\
1613(218)\end{array}$ & $\begin{array}{r}1132(193) \\
977(136)\end{array}$ & $\begin{array}{l}23 \cdot 7(11 \cdot 4) \\
22 \cdot 8(10 \cdot 0)\end{array}$ & $\begin{array}{l}647(135) \\
612(150)\end{array}$ & $\begin{array}{l}35.9(4 \cdot 5) \\
37 \cdot 7(6 \cdot 1)\end{array}$ \\
\hline 9 months & $\begin{array}{l}\text { Boys (25) } \\
\text { Girls (39) }\end{array}$ & $\begin{array}{l}9.60(1.4) \\
9.13(2 \cdot 1)\end{array}$ & $\begin{array}{l}1942(262) \\
1741(226)\end{array}$ & $\begin{array}{l}1243(208) \\
1113(163)\end{array}$ & $\begin{array}{l}22.6(8.8) \\
18.8(7.9)\end{array}$ & $\begin{array}{l}676(111) \\
610(154)\end{array}$ & $\begin{array}{l}34.9(4 \cdot 5) \\
34.8(6 \cdot 8)\end{array}$ \\
\hline 12 months & $\begin{array}{l}\text { Boys (25) } \\
\text { Girls (39) }\end{array}$ & $\begin{array}{l}9.23(1 \cdot 3) \\
9.70(2 \cdot 1)\end{array}$ & $\begin{array}{l}1986(318) \\
1872(226)\end{array}$ & $\begin{array}{l}1300(253) \\
1184(165)\end{array}$ & $\begin{array}{l}25 \cdot 0(10 \cdot 5) \\
19 \cdot 2(8 \cdot 0)\end{array}$ & $\begin{array}{l}660(112) \\
669(157)\end{array}$ & $\begin{array}{l}33.5(4 \cdot 0) \\
35 \cdot 6(6 \cdot 4)\end{array}$ \\
\hline
\end{tabular}

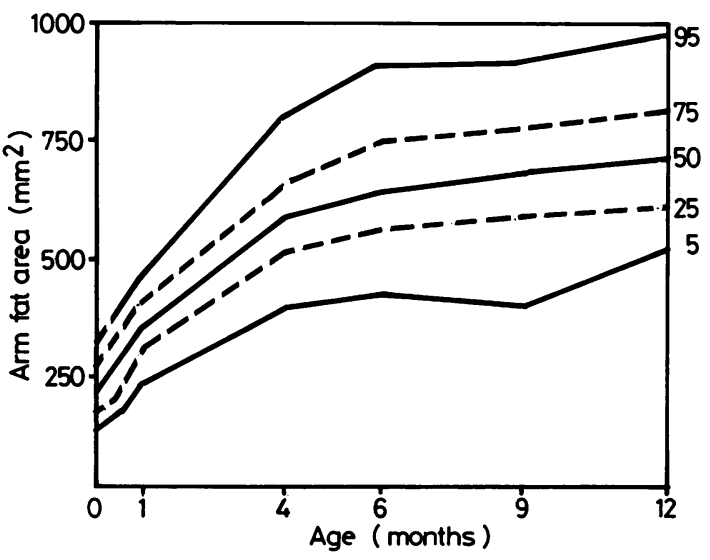

Fig 1 Evolution of arm fat area during infancy (in percentile). $A F A=A A-A M A . A A=\frac{M A C^{2}}{4 \pi}$.

area, which was greater in boys from the age of 1 month to 9 months of age. A significant increase of arm fat area was observed in each sex at the age of 15 days with a peak at the age of 6 months.

At birth and subsequently the arm water area represented only a minor part of total arm area since it was only $1 \%$ of the arm area. Therefore arm water area could be excluded from the calculations of both arm fat and arm muscle area. The figures give the new equations with TSKF15 and show the results expressed in percentile.

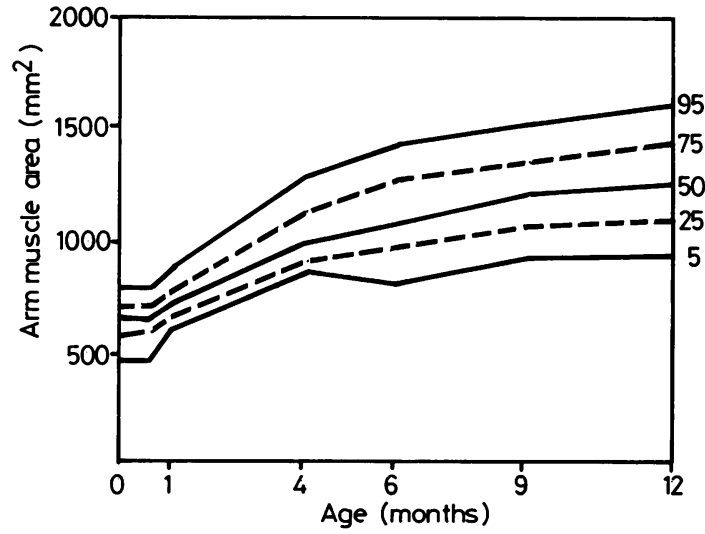

Fig 2 Evolution of arm muscle area in male infants (in percentile). $A M A=\frac{(M A C-\pi T S K F)^{2}}{4 \pi}$

\section{Discussion}

The methodological problems of this investigation are typical of longitudinal studies. ${ }^{9}$ The variability of measurement was avoided as much as possible as all measurements were carried out by the same investigator throughout the study. Additional studies also showed that the population was very homogenous. ${ }^{10}$ In addition, the usual anthropometric measurements were very close to the reference curves of French children of Sempé et al. ${ }^{7}$ We therefore 


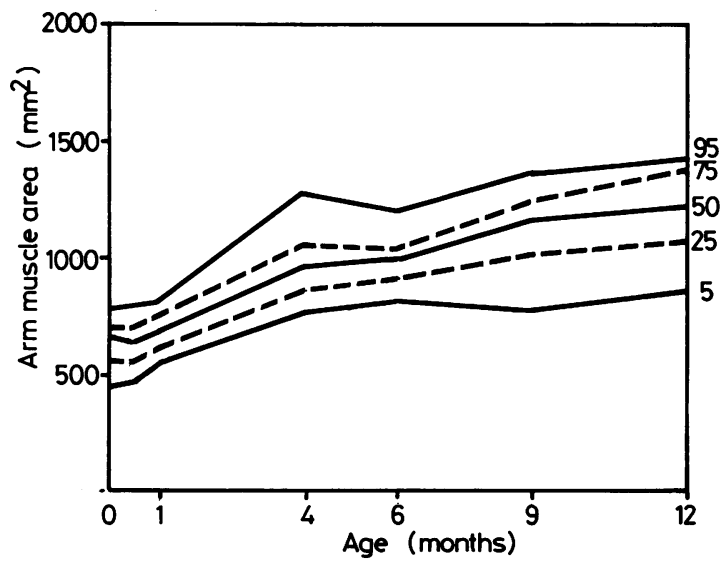

Fig 3 Evolution of arm muscle area in female infants (in percentile). $A M A=\frac{(M A C-\pi T S K F)^{2}}{4 \pi}$.

believe that these preliminary results are fairly representative of French infants.

The advantage of arm area over arm circumference and tricipital skinfold deserves some comments. Frisancho showed that these measurements do not estimate the magnitude of the tissue changes in the upper arm. ${ }^{11}$ This is due to the fact that for a given thickness of subcutaneous fat it takes more fat to cover a large limb than it does to cover a smaller limb. This is particularly important during infancy when there is a fourfold increase in fat body store in the reference male infant during the first six months of life: ${ }^{12}$ in male infants we showed a $50 \%$ mean increase in mid arm circumference, a $112 \%$ mean increase in tricipital skinfold, and the arm fat area increased threefold. Thus these results suggest that the arm fat area gives a more accurate evaluation of the evolution of the body fat accumulation; this finding is in agreement with the result showing that fat areas are systematically better estimators of weight of fat than skinfold thickness in children and adults. ${ }^{13}$

The equations for calculation, however, imply some assumptions such as the cylindrical form of the arm and the constant ratio of arm and humerus diameter. Recently an investigation using computed tomography was applied to adults and led to corrected equations for arm muscle area. ${ }^{14}$ The relevance of these corrected equations is unknown in infants, and to evaluate the influence of skinfold thickness compressibility and the role of interstitial water we introduced the dynamic change of tricipital skinfold in relation to total arm area. The present investigation shows that despite the large extracellular water component in young infants ${ }^{12}$ changes in tricipital skinfold and arm water area provide marginal information. As arm water area represented only $1 \%$ of total arm area, we consider that it can be neglected in the evaluation of other arm areas and TSKF15 can be used in the calculations. This suggests that in infants the difficult measurement at 60 seconds is not required.

Walker and Hendricks recently stressed the utilisation of arm areas in the evaluation of the nutritional state of infants. ${ }^{15}$ To our knowledge there are only two publications concerning infants: the standard based on data collected in the Ten State Nutrition Survey in the United States ${ }^{3}$ and the report of Martorell et al in Guatemala ${ }^{16}$; none of these studies were longitudinal and neonates were not measured. In the North American investigation only two determinations were obtained during the first year of life. The Guatemalan children could not provide normal values as some of them were undernourished.

The present results of measurements of arm areas are helpful in the evaluation of the nutritional state of infants. For example, an 8 month old slim looking boy with a weight of $6950 \mathrm{~g}$, a mid arm circumference of $138 \mathrm{~mm}$, and a tricipital skinfold of $6 \mathrm{~mm}$ would be at $-1.5 \mathrm{SD}$ for weight and mid arm circumference and at the 30th percentile for tricipital skinfold. If his arm fat area was $386 \mathrm{~mm}^{2}$, below the 5th percentile and suggesting depletion of calorie reserves, but his arm muscle area was 1129 $\mathrm{mm}^{2}$, this would show an adequate protein reserve. In a 4 month old girl with weight at -3 SD (4500 g), and mid arm circumference at -3 SD $(107 \mathrm{~cm})$ tricipital skinfold of $6 \mathrm{~mm}$ was not suggestive of depleted fat reserve; however, an arm fat area of $288 \mathrm{~mm}^{2}$ was below the 5 th percentile and so was the arm muscle area $\left(623 \mathrm{~mm}^{2}\right)$. A third example shows the evaluation of protein reserves: a 9 month old breast fed girl weighed $6500 \mathrm{~g}(-2 \mathrm{SD})$, had a tricipital skinfold of $11.4 \mathrm{~mm}$, and an arm fat area of $661 \mathrm{~mm}^{2}$, and they were around the 60 th percentile; but despite a normal mid arm circumference of $133 \mathrm{~mm}(-1 \mathrm{SD})$ the arm muscle area was low at $747 \mathrm{~mm}^{2}$ suggesting limited protein reserve. Thus measurements of arm areas are better indicators of fat and protein reserves than tricipital skinfold and mid arm circumference. In addition, measurements of the different arm areas can indicate whether it is the calorie or protein reserve that is involved in insufficient growth. Finally, as low measurements of arm areas are observed before inadequate weight gain they could help in the recognition and detection of marginal reserve depletion.

We thank Doctor Morin and JF Blanc from the Centre Hospitalier de Vienne for their help and collaboration. 
This study was supported by a grant of Observatoire Régional de la Santé, $\mathrm{N}^{\circ}$ 24-83.

\section{References}

1 Merritt RJ, Susskind RM. Nutritional survey of hospitalized pediatric patients. Am J Clin Nutr 1979;32:1320-5.

2 Jelliffee ERP, Jelliffee DB. The arm circumference as a public health index of protein calorie malnutrition of carly childhood. J Trop Pediatr 1969;15:179-88.

${ }^{3}$ Frisancho AR. Triceps skinfold and upper arm muscle size norms for assessment of nutritional status. Am J Clin Nutr 1974;27:1052-7.

${ }^{4}$ Gurney JM, Jelliffee D. Arm anthropometry in nutritional assessment: normogram for rapid calculation of muscle circumference and cross-sectional muscle and fat areas. Am J Clin Nutr 1973;26:912-5.

5 Thornton CJ, Shallon DL, Hunter MA, Brans YW. Dynamic skinfold thickness measurements: a non-invasive estimate of neonatal extracellular water content. Pediatr Res 1982;16: 989-94.

${ }^{6}$ Goujard J, Karminski M, Rumeau-Rouquette C. Moyenne pondérale et âge gestationnel en relation avec quelques caractéristiques maternelles. Arch Fr Pediatr 1973;30:341-62.

${ }^{7}$ Sempé M, Pedron G, Roy-Pernot MP. Auxologie. Methodes et séquences. Paris, France: Editions Theraplix, 1969.

${ }^{8}$ Brans YW, Sumners JE, Dweck HS, Cassady G. A non-invasive approach to body composition in the neonate: dynamic skinfold measurements. Pediatr Res 1974;8:215-22.
${ }^{9}$ Goldstein H. Sampling for growth studies. In: Falkner F, Tanner JM, eds. Human Growth. 1: Principles and prenatal growth. New York: Plenum Press, London: Ballière Tindall, 1978:183-208.

10 Picard J. Structure, classification et discrimination des profils évolutifs incomplets et asynchrones. Lyon, France: Université Claude Bernard, 1987. (Thesis.)

"Frisancho AR. New norms of upper limb fat and muscle areas for assessment of nutritional status. Am J Clin Nutr 1981;34: $2540-5$.

12 Fomon SJ, Haschke F, Ziegler EE, Nelson SE. Body composition of reference children from birth to age 10 years. Am J Clin Nutr 1982;35:1169-75.

${ }^{13}$ Himes JH, Roche AF, Webb P. Fat areas as estimates of total body fat. Am J Clin Nutr 1980:33:2093-100.

14 Heymsfield S, McManus C. Smith J, Stevens V, Nixon DW. Anthropometric measurement of muscle mass: revised equations for calculating bone-free arm muscle area. Am J Clin Nutr 1982:36:680-90.

15 Walker WA, Hendrirks KM. Manual of pediatric nutrition. Philadelphia: WB Saunders, 1985.

${ }^{16}$ Martorell R, Yarbrough C, Lechtig A, Delgado H, Klein RE. Upper arm anthropometric indicators of nutritional status. Am J Clin Nutr 1976:29:46-53.

Correspondence to Dr L Sann, Service de Pathologie Néonatale, Hôpital Debrousse, 29 rue Soeur Bouvier, 69322 Lyon Cedex 05, France.

Accepted 23 October 1987 